\title{
5
}

\section{Absence as Immoral Act: The PNG LNG Project and the Impact of an Absent State}

\author{
Michael Main
}

Inside Gigira burns Laitebo, which when kindled, the flames will illuminate Hela and the land beyond.

'The Hela Prophecy' (Cuthbert 2009)

\section{Introduction}

In May 2014, Papua New Guinea (PNG) exported the first shipment of liquefied natural gas from its newly completed Papua New Guinea Liquefied Natural Gas (PNG LNG) project. The PNG LNG project had been promoted as a nation-defining project that was predicted to 'transform the economy of Papua New Guinea' creating benefits that would 'improve the lives of Papua New Guineans by providing essential services' and declaring that the project's landowners 'stand to benefit from direct payment of royalties on production of gas and associated petroleum products, as well as improved social and economic infrastructure' (ACIL Tasman 2008: v). The project has since become synonymous with the struggle of aggrieved landowners against the social and economic failures of resource development, and the corruption and neglect of a largely absent Papua New Guinean state. Analysis has shown that in 
reality 'the PNG economy is in a worse state than it would have been if it stayed on the underlying growth path of the 2000s and had no PNG LNG project' (Flanagan and Fletcher 2018: 12).

The PNG LNG project began construction in the mountainous terrain of what is now PNG's Hela Province in 2010. The project took around four years to construct at a reported cost of USD19 billion, making it the largest and most capital-intensive resource project in the history of the region. The project is vast in scale and includes a purpose-built international airport at Komo (see Figure 5.1), a gas conditioning plant at Hides where the gas extraction wells are located (the Hides Gas Conditioning Plant (HGCP)), a $290 \mathrm{~km}$ onshore pipeline to the Omati River and a $407 \mathrm{~km}$ offshore pipeline beneath the Gulf of Papua to the LNG plant at Caution Bay. The large footprint of the project means that it affects a number of landowner groups. The HGCP and extraction wells are located along a mountain ridge, known as Hides Ridge, the Huli name for which is Gigira. The overarching agreement signed between the landowners for the project and the state is known as the Umbrella Benefits Sharing Agreement (UBSA), under which landowners in specific Petroleum Development License areas signed License Benefits Sharing Agreements (LBSA). The landowners of the gas resource are the Hulispeaking clans of Hela Province who have genealogical ties to land associated with the PNG LNG project, and whose representatives signed up to a series of LBSAs prior to the project's construction. These LBSAs also included development promises that pertain to the entire province, which is expected to benefit as a whole from the project. These agreements were signed between the landowners and the state of PNG, and included promises of direct royalty payments to landowners in addition to a range of infrastructure projects including the construction of roads and schools, power supply and medical centres. Landowners from other parts of the project such as the pipeline and the LNG plant at Caution Bay in Central Province also signed various agreements. This chapter focuses on the Huli population of Hela Province, who are by far the largest landowning population and the customary landowners of the gas resource. 


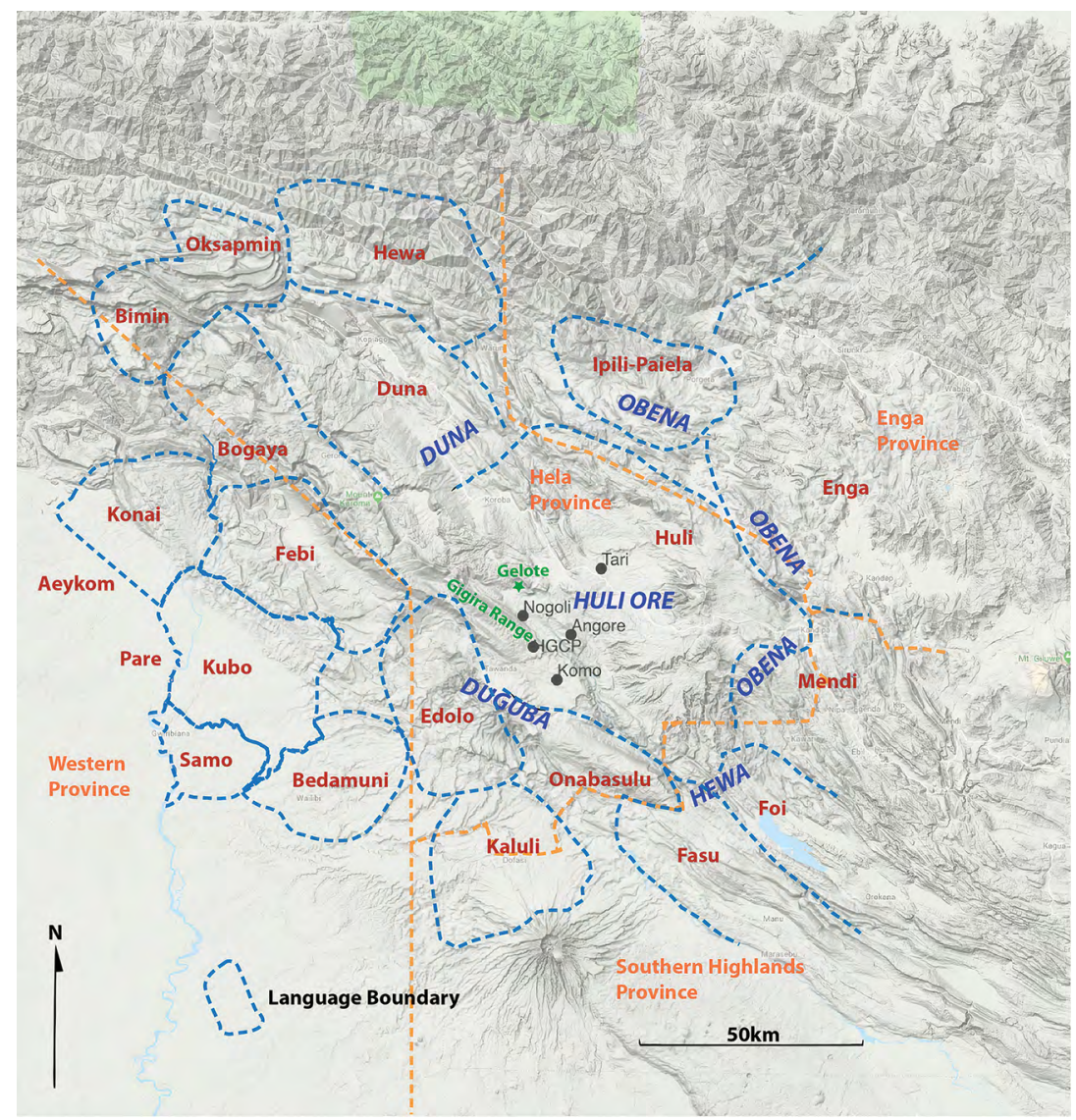

Figure 5.1 Hela geography

Source: Modified from Ballard (1995): Vol. 2, Figure B11

During fieldwork conducted in 2016, two years after the project began operating, it was immediately clear to me that Hela Province and its landowners had benefited little from the project, and it seemed that the majority of the population were arguably worse off as a result of the project. Frustration seethed among landowners at the absence of promised infrastructure and the failure to pay royalties because the landowners were yet to be officially identified by the state through the 'landowner identification' processes required under the terms of the Oil and Gas Act (see Filer 2019). Health and education services that existed prior to the project were in decline, and blame for the situation was largely attributed to the corrupt behaviour of politicians and various public servants. Yet the 
PNG LNG project remains a venture that defines Hela as a province, and even, as this chapter will argue, as an Indigenous nation for its majority Huli-speaking population.

The concept of the state itself has been a highly contested subject for social theorists. The state of PNG exists firmly as an idea in the minds of its citizens, despite the extraordinary diversity of its cultural terrain, hundreds of language groups, immense poverty, lack of state infrastructure and the inability of the state to project power to its own borders. For many Papua New Guineans, the state of PNG therefore exists largely in spite of its apparent absence. This chapter reverses the focus from James Scott's concern with how the state sees its citizens (Scott 1998), to an interest in how citizens view the state, and by extension, how it is that the state can exist at all when it refuses to see its citizens. This poses the obvious question: how can the state be described as something that sees or doesn't see? The state is not an object but the subject of itself, consisting of its own citizens, some of whom come to represent the state and occupy positions of state power. The state is not other to itself, and when it sees, it is doing the seeing of itself. This has important implications, as highlighted in this chapter, for when state officials are caught between their simultaneous roles as state representatives and state subjects. I take the view proposed by Chernilo 'that social theory's ambivalent attempts at conceptualizing the nation-state reflect the actual ambivalence of the position of the nation-state in modernity' (2006: 6). Out of this embrace of ambivalence that might liberate social theory from the need to define the state, I propose that the state be viewed simply as a value proposition held by a collective. The value propositions that form modern nation states are encoded and symbolised in ways that are common to all of these states: in foundational text, in national song, in flags and in the arts. This value proposition invests the state with a great deal of power, including the power to dispense justice. I would go as far to suggest that it is unreasonable to ask what it is that defines the state, because it is the undefined nature of the state that makes it possible for the state to exist. A better question to ask is: why does the state exist? The state is a desired and idealised collectivity with strongly defined borders. The state exists because it consists of subjects who collectively value its existence. The difference between a state and a nation is a legal one; both are value propositions that are collectively made. The question as to why humans have come to form collectives that value the existence of states is beyond the scope of this chapter. This understanding of the state creates the space 
for the state to be materially absent, yet still exist firmly as a set of values according to which the state should behave even if it does not. An analogy might be made with Lao Tzu's famous observation that the wheel is defined by the hole in the middle (Tzu 1963: 67). The state is an enabling constraint encircling the desire that the state should exist.

This chapter explores the role of natural resources in the value proposition that is the state of PNG. The country's Constitution includes the declaration of its fourth goal 'for Papua New Guinea's natural resources and environment to be conserved and used for the collective benefit of us all, and be replenished for the benefit of future generations' (GPNG 1975: 4). Former prime minister Sir Julius Chan's famous statement that PNG 'is a mountain of gold floating on a sea of oil' seeks to legitimise the state by establishing a natural resource base upon which PNG's founding values can be proposed. In the eyes of the state and the Huli landowners, these values ideally underpin the establishment of the PNG LNG project.

\section{Once Were Hegemonic}

At the beginning of the PNG LNG project's construction Hela did not exist as a province, and the Hela landscape was part of the larger Southern Highlands Province. Yet Hela did exist as a concept and calls for the creation of Hela as a separate province date to the 1960s. During a sitting of the third House of Assembly of Papua and New Guinea in 1974, Andrew Wabiria, member for the Koroba-Kopiago electorate of PNG's Southern Highlands District, moved a motion that called for the establishment of a new Hela Province to be carved out of the existing Southern Highlands District. ${ }^{1}$ It was not until the full potential of Hela's vast gas reserves began to be exploited by the PNG LNG project that the realisation of Hela as a province started to become a reality. By the time the province of Hela, covering an area of $10,498 \mathrm{~km}^{2}$ with an estimated population that in 2011 exceeded 250,000 (GPNG 2013), was finally established in August 2012, the struggle for its creation had become inextricably linked with the development of the vast natural gas reserves that exist beneath Hela's mountainous terrain.

1 Districts became Provinces when PNG became independent in 1975. 
The historical underpinnings of the contemporary notion of Hela need to be described in order to understand the contemporary relationship between Hela, the PNG LNG project, ExxonMobil and the state. The population of Hela Province is dominated by Huli-speaking clans that identify a geographical and cultural core of Huliness which includes the main township of Tari (Ballard 2002). The mythology at the basis for the concept of a Hela people involves an apical ancestor named Hela who was the progenitor of the five groups that occupy the Tari basin and surrounds. These five groups are derived from the offspring of Hela's four sons and one daughter: Huli, Duna, Obena, Duguba and Wana Hewa. ${ }^{2}$ This is the contemporary rendition of the Hela story, which has solidified into a neatly packaged concept that is widely accepted and understood across the population of Hela, and that has been disseminated through PNG's media to become part of PNG's national story. For Huli, Obena include Ipili and Enga groups to the northeast and east; Duna lie to the northwest; Duguba include Papuan Plateau groups to the south; and Wana Hewa to the southeast (see Figure 5.1).

Many different versions of Huli and Hela origin stories were in existence prior to the influence of the Australian colonial administration, which began in earnest during the 1950s. Following the exploration and/or exploitation of nearby gold, oil and gas reserves during the 1980s, Hela as a political project took on a much greater urgency, solidifying into a singular Hela narrative and vision of development for the province and its people. ${ }^{3}$ However, the concept of Hela itself pre-existed both the exploitation of natural resources, and the earlier influence of the Australian administration, as did a Huli hegemonic tendency towards the material and cosmological control of their entire known world. After the first Patrol Post in Huli territory was established at Tari in 1951, the early patrol officers soon realised that the people of the Tari area were part of a much broader understanding of a Hela people: 'The word Hela Huri ${ }^{4}$ is often heard and seems to embrace all true Huri people' (Esdale 1955: 21). Esdale's interpretation of the word 'Hela' as 'altogether' or 'one kind', while semantically incorrect, does describe the sentiment

2 Wana Hewa is usually contracted to Wan Hewa in common parlance. Other versions have Wana Hewa as a son, rather than a daughter, however the version that includes a daughter has emerged as the dominant mythology.

3 These include the Mt Kare gold rush in neighbouring Enga Province, and gas exploration undertaken by BP in what is now Hela Province.

4 Huli was initially spelled as 'Huri' by the Australian administration during the 1950 s. 
of a people united by a singular, apical ancestor named Hela. Hela is simply the name of the apical ancestor described above. The idea of Hela, as it is held by its Huli-speaking majority, may be reasonably described in terms of an Indigenous nationhood. If we take Benedict Anderson's (1983: 49) model for nationhood as a community where most people are unknown to each other and 'yet in the minds of each lives the image of their communion', then the size and extent of the shared historical, cosmological and genealogical understanding of Hela, linked by extensive trade routes and ritual connections, is a snug fit. This understanding of nationhood is incorporated by my definition of the state, and there is no reason why the two cannot coexist, as one value proposition encompassed by another. The state of PNG is able to incorporate a diverse range of Indigenous groups who all subscribe to the value proposition that is the state, which is something that Huli have done enthusiastically since PNG gained independence.

Huli view themselves as having a central location in relation to surrounding groups, and have historically imposed their own hegemonic understanding of themselves on their neighbours. This understanding is realised simultaneously in terms of their trading relationships, mythical genealogical recall and cosmology. At this point it should be stated that much of Huli traditional knowledge has either vanished or been radically transformed over the past few decades; however, what is being described here does provide the foundation for contemporary Huli understandings of themselves and of their relationship to both the PNG LNG project and the PNG state. In cosmological terms the most important Huli ritual site was a place called Gelote, which roughly translates as 'the support of the universe' (Goldman 1981: 75). This site was at the centre of a vast cosmological system known as dindi pongo ('root of the earth') that linked together several other ritual sites that are dotted across the extent of Hela. Gelote was also referred to idiomatically as dindi hanuni, or 'the middle land'. 5 In material terms, Huli are situated centrally in relation to their trading partners. Prior to colonial intervention, Huli not only identified themselves as being at the cosmological centre of the universe, but also played a central role in the control of regional trade (Ballard 1994). Here I differ from Aletta Biersack when she writes that Huli, Duna and Ipili people "were "ex-centric," centred not on themselves as geographical isolates but on the culturally diverse field in which their mythology, 
trade routes, and marriage practices embedded them' (1995: 7). Huli did not consider themselves to be 'geographical isolates', but their geographical connectivity was certainly centred upon themselves, which was also recognised by their neighbours as Huli functioned as a regional trading language. Indeed, their centrist and hegemonic understanding of themselves depended upon their connections throughout the diverse field that surrounded them.

Much has been written on the cosmological underpinnings of this expansive Huli world-view (Goldman 1983; Frankel 1986; Ballard 1994, 1995), but economic factors in the form of trade routes and centres of production peripheral to a centralised Huli-controlled trading zone are at least equally important to providing an understanding of the Huli-centric notion of Hela, and it is these material concerns that have transformed to become the most important aspect of people's lives. As Tom Ernst writes, 'The degree of freedom of movement by Huli and to Huli territory is more likely to have been "the peace of the trade" than a commonly subscribed to Huli ritual or cosmological hegemony' (2008: 31). Today the primacy of these material concerns has emerged as the strongest motivator of contemporary events. The PNG LNG project has returned Huli to the centre of economic activity, which is a position to which they feel both cosmologically and historically entitled. The major difference between the present situation and the past is that power is now located external to Huli territory, and the material destiny of Hela is largely in the hands of the state rather than Huli themselves.

Huli have retained an understanding of their historically superior status at the centre of economic activity, and have incorporated the existence of gas reserves into their trading cosmology. A Huli friend in Tari explained to me his understanding of the history of Huli trading relationships in the following way:

Engans get salt, they cut small trees and throw them into a spring and stay for months in the water. Salt crystals grow on the wood. Then they dry and burn the wood and collect the salt to make bundles of salt. The Engans (Obena) want to trade with Komo people, but not the Tari Huli. Men from Hulia (Tari Huli) stopped the Obena from travelling down to Komo and Bosavi by telling the Obena that the Duguba people will eat them. Obena are fatter, stockier people and the Duguba will like to eat them. It is safe for the skinnier Huli to trade with the Duguba, so they take the salt from the frightened Obena and trade with Duguba for cassowary 
feathers and bones, bird of paradise feathers, tree oil, and wood that Huli use to make bows. The Huli give some of these things to Obena people but keep the best for themselves. Huli people must keep the Obena and Duguba people apart. The prophecy states that one day they will see each other and then an eternal fire that exists beneath the Gigira Range, the Lai Tebo fire, will light all the way from Gigira to Obena territory.

This is now interpreted to be the power line that runs from Nogoli to power the Porgera Gold Mine. Nogoli is located about $20 \mathrm{~km}$ southwest of Tari and is the site of the gas turbine that generates power for Porgera in neighbouring Enga Province.

This cosmological aspect of the Huli trading relationship, expressed as a desire to prevent the meeting of the Duguba and Obena people lest the land be destroyed, has been described by Ballard (1995). ${ }^{6}$ The economic and cosmological drivers for this concern are not easily separated, and my opinion is that the movement of people across distances amounting to tens of kilometres into neighbouring territories should be viewed through the lens of the primacy of material interests. Huli cosmology more broadly, I would argue, needs to be understood in material terms, and it is these material desires that are driving the reconfiguration of Huli cosmology to incorporate the presence and extraction of natural resources. This view is supported by Huli themselves who consistently describe the purpose of their cosmological rituals in terms of the maintenance and resurrection of the fertility 'of the entire universe' (Ballard 1994: 142). With the development of the PNG LNG project, the material underpinnings of Huli cosmology are well and truly dominant, but the power to realise material desires is in the hands of the state.

\section{A Prophecy of Abundance and the Immorality of an Absent State}

The PNG LNG project is so vast in scale and conception that its gravitational pull has reduced the development aspirations of Hela to a singularity. Every hope and dream of every Hela citizen was expected

6 Ballard reports 'a somewhat cynical young Huli businessman' who posited that 'this stricture was formulated by his ancestors precisely to maintain the monopoly enjoyed by Huli on the lucrative trade between Obena and Duguba groups of such wealth items as salt, tree oil and blackpalm bow staves' (Ballard 1995: 57). 
to be realised via the LNG wealth that had been imagined without end. PNG LNG was imagined by the project's main protagonists, ExxonMobil and Oil Search, and the PNG state, as well as the Huli population, as a paradigm shift in the material landscape of the people and of the future. To an extent, Huli had been here before when in the 1660s the Long Island volcano erupted and changed their world utterly and instantly. A Plinian eruption of equivalent magnitude to that of Krakatau in 1883 deposited a layer of volcanic ash across the PNG highlands (Blong 1982). Huli stories of a time of darkness, known as mbingi in Huli, were first recognised as being related to this eruption by Blong (1979). The details of the stories varied, and were recorded by the first patrol officers assigned to Huli territory during the 1950s. During a patrol into the Komo basin from Lake Kutubu, Charles Terrell (1953: 18) recorded a story about a time of 'white rain' when the sky became dark and 'white stuff that was like the ground' fell for seven days. After that event the people found that their sweet potato crops grew faster than they had before. The volcanic ash brought such enhanced fertility to the soil that ritual practices emerged that were dedicated to bringing on the event again. Crucially, the line between disaster and renewal was finely balanced and depended on correct moral behaviour and observance of strict moral codes, breaches of which are known in Huli as ilili (forbidden act). Improper behaviour could result in the failure of mbingi and the destruction of the entire known Huli universe.

A preoccupation with mbingi combined with the rapid embrace of Christianity from the mid-1950s onwards was shown by Ballard (2000) to have intersected neatly with Christian notions of the apocalypse and, in particular, the role of human moral agency in bringing about the destruction of the land. One of the most enduring features of a Huli world-view has been the perception that the world is in a constant state of decline. This 'entropic' perception of the Huli universe has been influenced by recurring natural events such as droughts and floods and much of Huli ritual was devoted to reversing this downward trajectory of material and social change (Ballard 2000: 207). By the time of the PNG LNG project, the cultural memory of mbingi was in retreat and the time of darkness was no longer evoked in Huli expectations of the future. But an expectation of apocalyptic transformation remained as a habitus of anticipation that was ready and open to the promises of PNG LNG to which Huli believed themselves to be ancestrally entitled. PNG LNG became the new mbingi and the prophecy known as Gigira Lai Tebo (see below) was elevated into 
the realm of truth and demonstrable fact, evidenced unmistakably by the giant fire that burns day and night from the top of ExxonMobil's flaring tower. As a technical-political project, the PNG LNG project is also finely balanced between success and development failure. Notwithstanding the technical success of the PNG LNG project, and its ability to generate revenue for the companies and their investors, from the point of view of its Huli landowners, the immoral behaviour that has tipped the project towards development disaster is found in the corruption and neglect of an absent state. The immorality of state absence is a material threat to the future aspirations of Huli and the prophetic entitlement of Hela to benefit from its gas.

\section{Gigira Lai Tebo}

As stated above, the gas resource for the PNG LNG project lies beneath a northwest-southeast limestone mountain ridge commonly known as Hides Ridge. The Huli name for this mountain is Hari Gigira (Mt Gigira). ${ }^{7}$ ExxonMobil drilled its gas wells along this ridge and constructed its vast Hides Gas Conditioning Plant (HGCP) towards the southeastern end of the ridge between 2010 and 2014 (see Figure 5.1). The topography of the Gigira Range results in soft cloud formations that settle blanket-like and fall down the sides of the range. The effect is similar in appearance to the white smoke that oozes from the kunai-grass roofs of Huli houses when a fire is burning within (see Figures 5.2 and 5.3). This visual effect is the source of the belief that there is a fire that burns beneath the Gigira Range. Huli houses are built with a central fireplace that is fed by long pieces of split firewood extending towards the doorway. The hardest and hottestburning firewood comes from the lai tree (Dodonaea viscosa), commonly known in Australia as sticky hop bush, of which an unusually tall variety grows in the PNG highlands. The Huli word 'tebo' refers to the glowing coals of a fire. Running beneath the Gigira Range is a giant, burning piece of lai wood-the Gigira Lai Tebo. The Gigira Lai Tebo story is one of many Huli mythological tales that relate to land formations across Hela. One of the LNG ships dedicated to the PNG LNG project even bears the name 'Gigira Laitebo' (see Figure 5.4).

7 Hari means 'mountain' in Huli. Gigira is a range or ridge formation rather than a mountain peak, however, hari is a more generalised descriptor for a mountain form rather than a geographically specific mountain peak. 


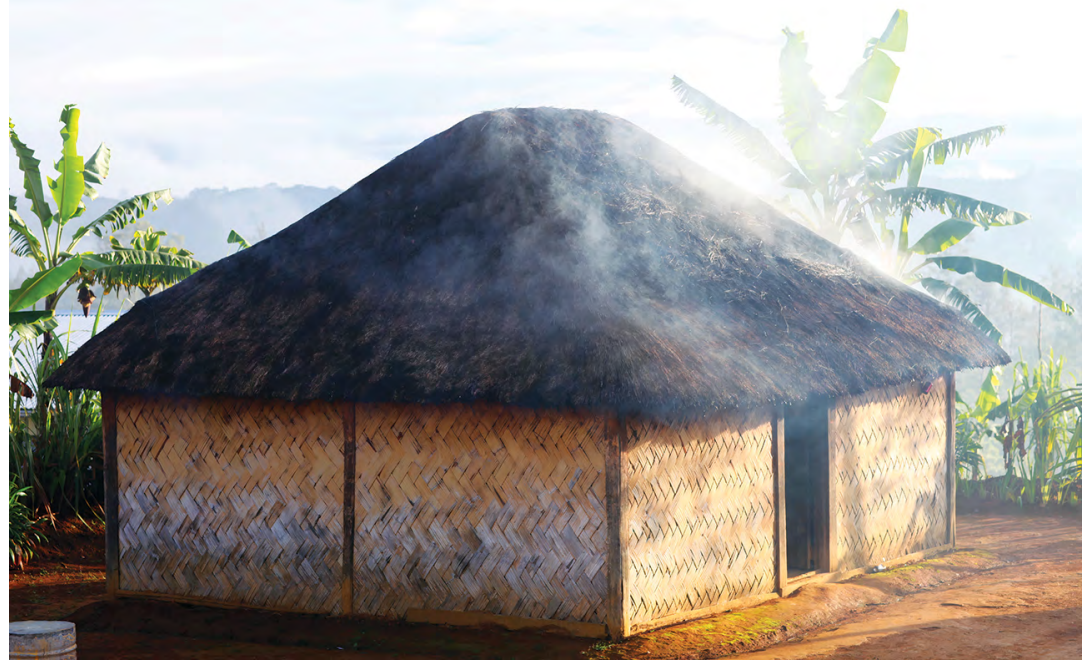

Figure 5.2 Huli house with smoke oozing through the roof

Source: Photograph by author

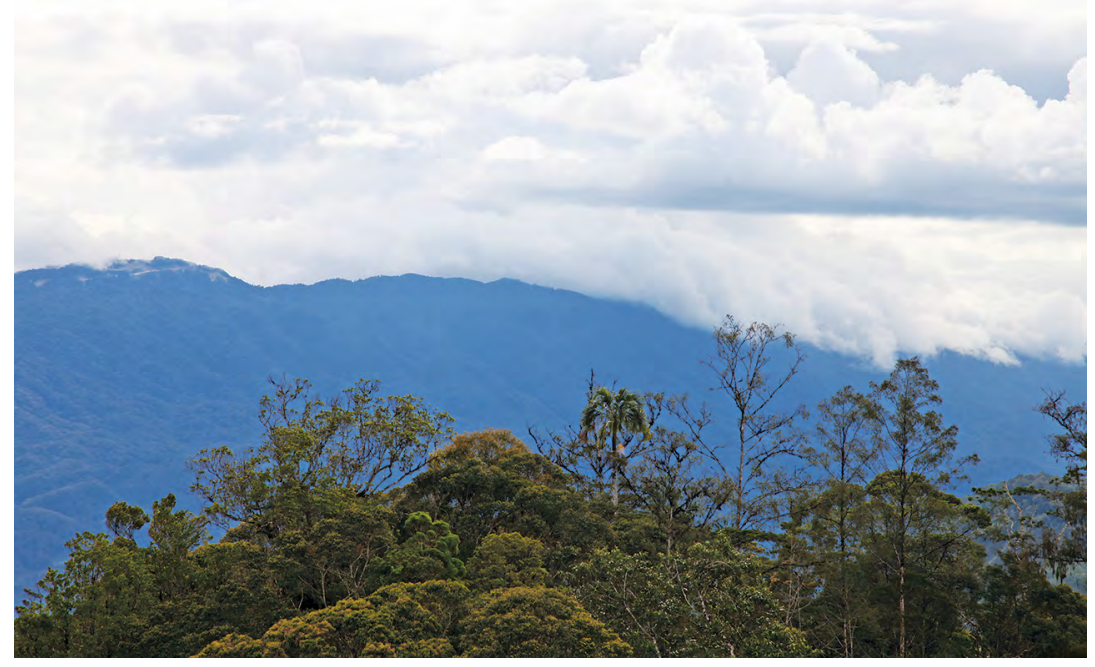

Figure 5.3 Gigira Range with cloud

Source: Photograph by author 


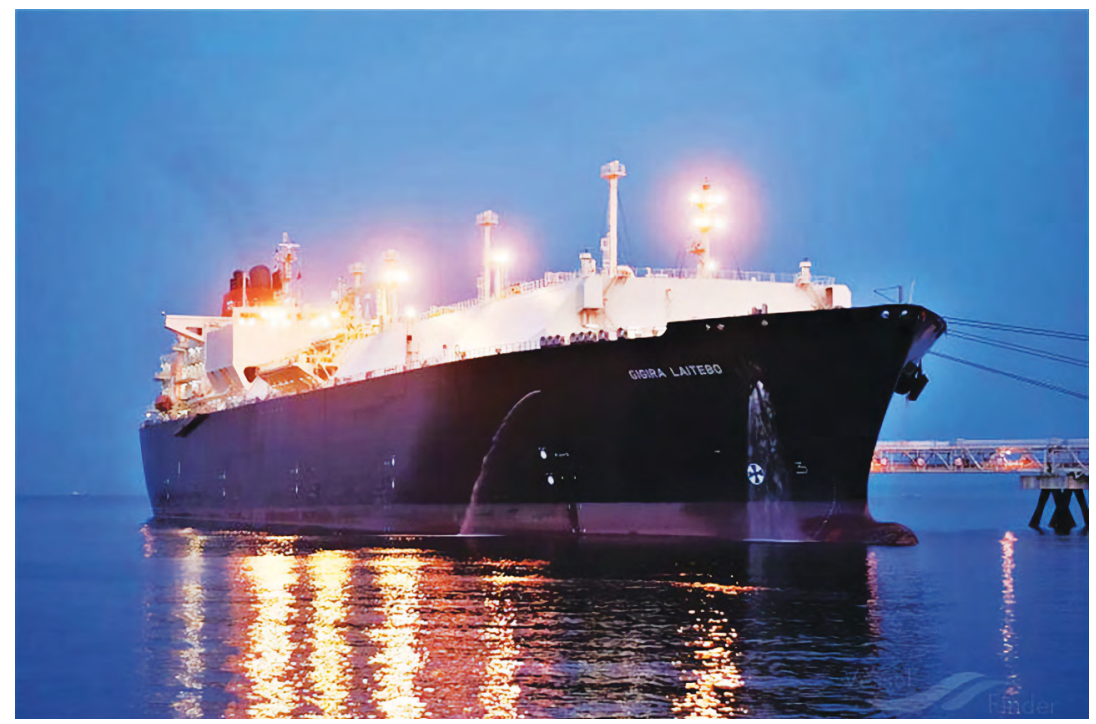

Figure 5.4 Gigira Laitebo ship

Source: Geraldo Pietragala on VesselFinder (www.vesselfinder.com)

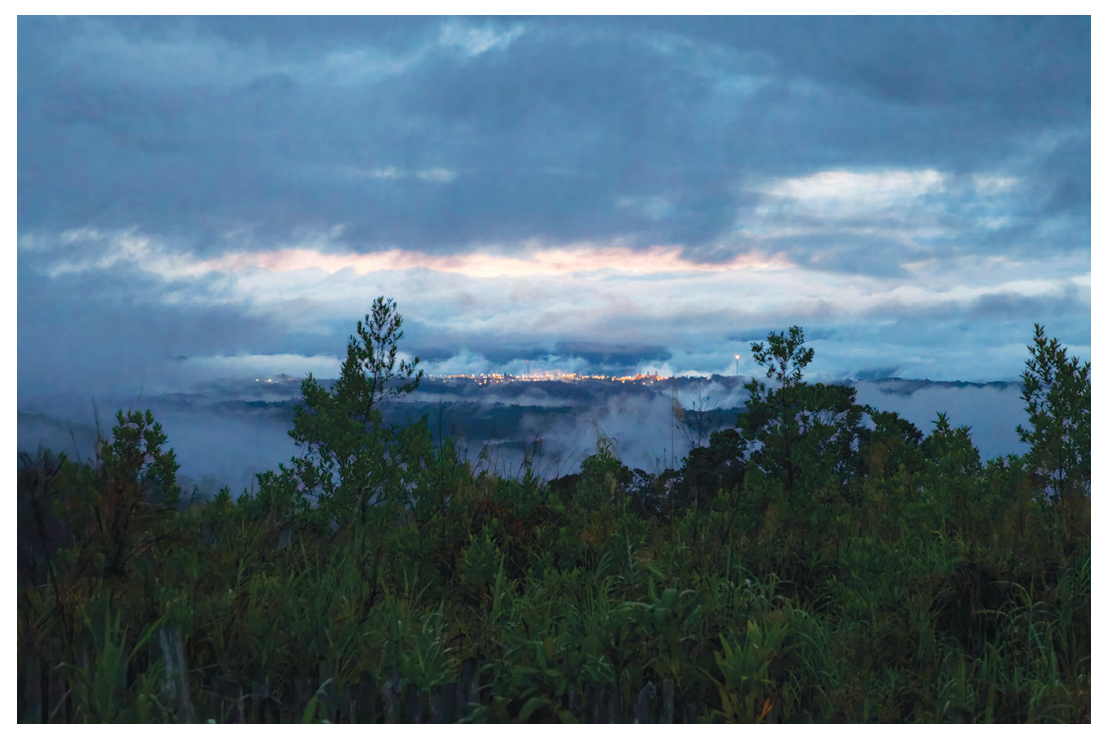

Figure 5.5 ExxonMobil's HGCP on Gigira Range

Source: Photograph by author 
When gas extraction wells were first drilled on Gigira, people living on the slopes of the Gigira Range fled their homes in fear that they would be engulfed by the Gigira fire. The fact that ExxonMobil built its conditioning plant and gas flare on the mountain further cements the legend. Figure 5.5 shows the visual impact of the PNG LNG project on the landscape. The prophecy associated with the project is widely known and was often repeated to me whenever I asked anyone about the PNG LNG project: One day a man with red legs will come to take the Gigira fire. You may share with him some of the fire, but do not give him the whole fire lest the world will end. Everyone who told me this story concluded with the observation that the Huli have given away the whole fire.

The Gigira Lai Tebo prophecy has not featured in previous academic literature, although it has featured occasionally in PNG media reports since the PNG LNG project began, and little was known about its detail prior to the PNG LNG project. In 2009, just prior to the construction phase, the prophecy was described in a blog post that was published by the son of former schoolteachers at Lake Kutubu (Cuthbert 2009). Cuthbert wrote 'Inside Gigira burns Laitebo which when kindled, the flames will illuminate Hela and the land beyond'. He went on to say: 'When the man with the orange legs comes to take the fire from you, give him an axe and tell him to go get his own firewood for his own fire.' In 2016 I visited areas on the slopes of Gigira Range that I was told were now uninhabited because the people had moved away in fear of the fire spilling out. Warnings that the world will come to an end as a result of prohibited human behaviour is a Huli trope that is common to the majority of Huli prophetic understandings.

\section{A Nation-Defining Resource within an Absent State}

Historically, Huli have observed deterioration in productivity of the land, epidemics of disease, increase in social disorder and warfare, floods, drought and earthquakes as representative signs of the decline of the Huli universe (Ballard 2000). Humans had a role in controlling the fate of the universe by observing ilili codes, and implicit in the decline of the universe was failure to observe these moral codes (Ballard 2000). Giving away the Lai Tebo fire was one such act encoded in prophecy. During my 
time in Hela, signs of the Lai Tebo prophecy playing out were expressed in observations about the general malaise of Hela Province, increasing conflict, corruption, a decline in basic services and a general increase in poverty. Hela was rich in resources and therefore entitled to benefit from those resources. In moral terms, Hela's resources belonged to Hela itself, and to its people, and the state had a duty to facilitate Hela's development. The understanding that PNG's customary landowners are also the owners of the natural resources that exist beneath their customary lands is a commonly held view that Filer (2014: 79) describes as part of 'the founding fiction of the independent state' (see also Bainton and Skrzypek, Chapter 1, this volume). I would argue that this is one of the founding values of the independent state, which persists regardless of its legal standing. Huli have a cosmological entitlement to Hela's resources, and the historical and cultural depth to this entitlement precedes the colonially introduced legislative tradition that grants ownership of resources to the state. Moral failing therefore resided partly with Huli themselves, who had clearly given away their fire for nothing. But most of the blame was laid upon the state for failing to deliver on its promises, and therefore failing to live up to itself as a value proposition. The LBSAs had been negotiated and signed between landowners and the state, and it was the state, therefore, that landowners expected to make good on its promises. The nonappearance of promised development infrastructure represented the material absence of the state. The breaking of promises and demonstration of neglect represented the moral failing of the state. The failure of state officials to respond to the concerns of landowners was a demonstration of the absence of the state in moral terms.

Crucially, references to the Lai Tebo prophecy were based on observations of material decline primarily witnessed through a lack of government services and decaying infrastructure, rather than natural phenomena. The 2015-16 drought that severely impacted much of the highlands was coming to an end, and its impact was noted in terms of the lack of government response and the fact that the majority of people still had to eke out an existence as subsistence farmers. One reported example was the failure to maintain downpipes and water tanks at schools, which resulted in the forced closure of many schools due to lack of water (Bourke et al. 2016). The same report documented an increase in the crude death rate as a result of the drought. Development was expected to change the dependent relationship that people have with the land. The potential for development to save lives in the context of the drought and the failure 
of the state to realise that potential is a classic case of structural violence (Galtung 1969). It is also a failure of the value proposition that constitutes the state's existence. Drought was therefore a phenomenon that served to highlight the lack of development and the extent of state neglect in the province and their continuing dependence upon the land. The same can be said for the magnitude 7.5 earthquake that struck Hela Province in February 2018, as described later in this chapter. The PNG LNG project was widely regarded as a tool of the state to enable it to provide development in the form of infrastructure, health and education services, business development, employment, and cash for the landowners. Some landowners even expressed a certain level of sympathy for ExxonMobil because, like them, it had no choice but to deal with a corrupt state.

\section{Attacking the State by Proxy}

This sympathy was expressed in a letter to ExxonMobil that was drafted by a group of landowner leaders who had gathered near the Hides conditioning plant to organise a blockade in August 2016. These leaders had taken their case to the Supreme Court in Port Moresby to have PNG LNG project royalty payments, that were supposedly being held in abeyance, released to them and their clans. Two leaders in particular, who had previously been rivals for the leadership of the Petroleum Development License 7 (PDL7) landowner's group, had united in their efforts against the state. ${ }^{8}$ When they finally got their day in court, the court turned down their application on the basis that they had not demonstrated themselves to be legitimate landowners. As a result, they took matters into their own hands and came to Gigira and the epicentre of the PNG LNG projectthe conditioning plant compound. I was invited to witness the drafting of the letter to ExxonMobil. The letter was addressed to Andrew Barry, managing director of ExxonMobil PNG, and it politely and apologetically explained the reason that the project had to be shut down and made promises that no ExxonMobil property or personnel would be harmed. The authors specifically requested that ExxonMobil turn off the gas flare that burns within the compound. They drew an explicit distinction between the gas agreement that had been signed between the state and the developer in 2008, and the UBSA that had been signed between the

8 The Hides gas field and HGCP are located within the boundaries of PDL7. 
state and the landowners in Kokopo in 2009. The letter explained in some detail the grievances between the landowners and the state and finished with the following statement:

Thus we do not have hope and trust in this government as they continue to dishonour the agreements entered in to in Kokopo and in Hides respectively.

Therefore we PDL 01, 07 and 09 landowners are calling on Exxon and its partners to voluntarily shut down the HGCP and well pads $\mathrm{B}$ and C. We also want Exxon to put off the flare in the HGCP so that the whole operation can be shut for indefinite period until the state responds to the petition positively.

Thank you so much for your cooperation.

The landowner leaders' grievances were quite clearly directed towards the state rather than the company. In establishing a 'social license to operate' for the PNG LNG project, ExonMobil had been an outspoken advocate of the benefits that the project was expected to bring to the landowners. Prior to the project's construction, ExxonMobil had promoted numerous expected benefits from the project via its community affairs officers as they engaged with local communities. Yet when it came to confrontation over the failure of the project to deliver on its promises the landowner leaders directed their concerns to the state rather than the company. Why did these leaders focus almost exclusively on the state and not consider the responsibility of ExxonMobil and the potential for it to engage directly with the development of Hela Province, as Oil Search has done via its investments in the Hela Provincial health system?? I argue that the landowner leaders at PNG LNG were representatives of Hela, while the state of PNG is legitimised by its valued role in facilitating the viability of Hela and its transformation into a wealthy and prosperous example of a desired Papua New Guinean modernity. ExxonMobil is regarded as a tool, as an exclusively material entity being used by the state for its own benefit. The landowner leaders viewed ExxonMobil as a pawn in a larger game of corruption that was being played out by various levels of government and the judiciary. During the course of my fieldwork several people made the comment to me that ExxonMobil was just a company doing its job. ExxonMobil, in their eyes, was doing exactly what it was

9 Oil Search, via the Oil Search Development Foundation, has taken over the Hela provincial health system, including significant upgrades to the Tari hospital. A common complaint made to me was that ExxonMobil should behave more like Oil Search. 
supposed to be doing: extracting gas, selling the gas for a profit, and paying royalties and taxes to the state. ${ }^{10}$ It was the state, therefore, that had the responsibility of passing on agreed royalties and benefits to the people. Poorly understood by the landowners, however, was the aggressive tax-minimisation regime that the state had signed up to with the PNG LNG project. Details of this regime were reported by a World Bank investigation that attributed the lack of state revenue from the project to a complex web of exemptions and allowances that effectively mean that little revenue is received by government and landowners, either through taxes, royalties or development levies' (World Bank 2017: 27).

The landowner leaders were playing a dangerous game and, after two days, having received no response from ExxonMobil, they organised their clansmen to lock the main gate to the HGCP and blockade the project. My companions would not take me back up to the HGCP to witness these events as they were concerned for my safety and were worried about the potential for a shootout between the landowners and the police mobile squad that was stationed to protect the project. When I did return to the HGCP the next day, I was told by one of the landowner leaders who was the main organiser of the blockade that he had directed all his people to get hold of any weaponry they had and to enter the HGCP and lock the gate. The landowners responded by arming themselves and approaching the gates of the HGCP, compelling security personnel to step aside and allow them in. The organiser of the blockade then ushered the landowners back out and the gate was locked. Landowners also attempted, albeit unsuccessfully, to shut down the gas wells by breaking through the security fences that surrounded them and manually turning off the taps. When I later spoke with members of the police mobile squad, they told me that they had no intention of risking their lives by going against the landowners in defence of ExxonMobil, and they could see for themselves that the landowners were getting nothing from the project. The landowner leaders stated that the project would remain in lockdown until the government came to listen to their concerns.

10 This contrasts with the situation in Lihir, where landowners have maintained very strong expectations that the mining company will deliver development (see Bainton 2021; Bainton and Macintyre, Chapter 4, this volume). 
Four days later the state responded by materialising at Gigira on the playground of the local school at Para to face questions from landowner leaders. ${ }^{11}$ This was a crucial moment of state presence that stood in stark contrast to the experience of state absence that had thus far defined the relationship between the Huli landowners and the state. The landowner leaders had a very good grasp of the complexities of the gas agreement, and were able to hold their own when arguing about various forms of equity, well head production values, the value of LNG shipments and the amount of money that the government was receiving. The majority of landowners in the crowd, or people that I met at the market also spoke of royalty percentages, the number of LNG shipments to date and the structure of the state's Alternative Dispute Resolution (ADR) process that was then underway, which had failed to resolve any of their issues over landowner identification and the distribution of benefits. ${ }^{12}$ The questioning was aggressive and accompanied in equal part by a torrent of abuse and threats that rained down upon the delegation for several hours in the baking sun. The highlight of the event was the moment the finance minister and Huli member for Tari-Pori, James Marape, was challenged to partake in a ritual practice known as dindi nabaya, which translates as 'we eat the ground'. The challenge was made by a representative of the Juha landowners who had questioned Marape about the fate of certain development funds, in response to Marape's answer, which was considered to be a lie by the majority of the crowd. In situations where people have competing claims over the historical truth of land ownership, the practice of dindi nabaya, which entails each person eating a handful of the disputed land, serves as a way of divining the truth. The land itself, being the subject of the argument, is the material objectification of a singular truth being disputed. The person who is lying about the truth of land ownership, specifically about the historical truth claims made in relation to the land, will become sick and die as a result of eating the land. Death is not instant but may take some months. This was perhaps a novel application of dindi

11 The government representatives included the Huli finance minister James Marape (who later became the prime minister of the country in 2019), the prime minister's departmental secretary, the managing director of the Mineral Resources Development Corporation (MRDC) Augusten Mano, the mining and petroleum minister Nixon Duma, the managing director of Kumul Petroleum Holdings, the secretary for the Department of Petroleum and Energy David Manan, the member for Koroba-Lake Kopiago Philip Undialu, and the district administrator for Hela William Bando.

12 Many landowner leaders were in dispute over the identification of landowners and the failure to undertake a proper process of landowner identification. Once these disputes were taken to court, Justice Ambeng Kandakasi ordered that landowner benefit distribution be halted until the landowner issues could be resolved through the ADR process (Filer 2019: 41). 
nabaya, but the intent was clear. Marape was invited to come down off the stage and the crowd parted to create an open space for the two men to perform the ritual of dindi nabaya. His response to this ritual challenge was stunned silence. His evident fear and non-response was damning. And for many people in the crowd it represented the moral failure of the state.

Apart from the appeal to Huli tradition in the invoking of dindi nabaya, there was no invoking of the Gigira Lai Tebo prophecy or any other mythological understanding. The arguments were well-informed, pragmatic, and based on the material concerns of the landowners. The appeal to dindi nabaya was a body blow to the finance minister, as it was personal and a way of weaponising a shared ancestral and spiritual connection to land. The invoking of dindi nabaya was an extension of its original application in land disputes. Marape and the landowners were not arguing over land ownership, but over the truthfulness of Marape's statement about the fate of money that had been generated by the PNG LNG project. The landowner leaders decided that Marape, as a son of Hela, had a moral duty to tell the truth about Hela's resources; his duty to the state was secondary. Marape's silent response was taken by the crowd as evidence that he understood that his primary moral duty was to Hela. In the nation of Hela, state trumps company, but land trumps them both, and as a Huli it was generally expected that the Papua New Guinean finance minister James Marape's first duty was therefore to Hela.

\section{Hela Trumps State}

Prior to independence, Huli eagerly subscribed to the value proposition that was the colonial state. For Huli, the colonial state was symbolically represented by the crown worn on the policemen's headwear. When I asked John Hocknull, the last patrol officer to be stationed at Komo until independence in 1975, how Huli at Komo reacted to independence, he responded that the strong reaction was not to independence, but earlier when the national emblem of PNG replaced the crown that was worn on the policemen's uniform. The crown had been recognised as the head of power, out of which all social order emanated, and its removal, according to Hocknull, was like the sky had fallen in. Huli desire a benevolent power that is invested in the state, but if the state itself is absent then decay and disorder is the feared result. This is crucial to understanding Huli perceptions of the independent state as a value proposition. Today the 
absence of the PNG state in Hela, and especially in the remoter areas of the PNG LNG project operations at Komo and Hides, is palpable. When the landowners attacked the PNG LNG project, they were not attacking ExxonMobil but the state of PNG. Hela, much like the imagined state of PNG, or the imagined status of the crown, is constituted as an idea, and has more salience in its idealised form than does the material presence of the world's largest oil and gas company, which was ideally understood as a tool of the state. The landowners did not attack the tool, but the entity that wielded it. The state, constituted as an absence, and therefore as a value proposition that has collapsed, only loomed larger as its absence became the defining issue of the conflict.

Crucial to understanding Huli perceptions of ExxonMobil and its material presence in Hela is the perceived relationship between the PNG LNG project and the land. Unlike other extractive projects in PNG, or some large-scale mines in Australia (see Everingham et al., Chapter 9; and Lewis, Chapter 8, both this volume), the environmental footprint of the PNG LNG project is relatively benign. What impact the PNG LNG project has on the landscape consists mainly of infrastructure: the Komo airfield, the gas conditioning plant, even the waste incinerator, are all viewed as orderly and technologically advanced examples of material development. Unlike the Ok Tedi and Porgera mines, there is no production of waste material or tailings being disposed in the river system (see Golub, Chapter 3, this volume). Land ownership in Huli, or more accurately custodianship, is as much about the historical use of the land as it is about genealogical connections to land. It is beyond the scope of this chapter to detail the complexities of Huli land ownership. However, one feature that is relevant here is the fact that it is possible to lose rights over land through neglect. If your garden is allowed to become overgrown and go to waste then you are at risk of someone else coming along to work and improve the land and thereby gain rights to its occupation. Neglect of land is regarded as a moral failing. If you allow the land to go bad by allowing it to become overgrown with weeds and fail to put the land to some productive use then someone else has a moral right to occupy and improve the land. In this sense, ExxonMobil is doing work to the land and has a degree of user rights as a result. Had the PNG LNG project resulted in pollution to large tracts of land and waterways it is likely that ExxonMobil would have been imagined as an active agent in the destruction of Hela and it is arguable that the PNG LNG project would not have survived for as long as it has. 


\section{A Seismic Presence}

On 26 February 2018 Hela was hit by a magnitude 7.5 earthquake. The earthquake caused devastation to the landscape and people and caused significant damage to the PNG LNG project. Several days later, on 2 March, ExxonMobil declared force majeure on exports of LNG and the project was shut down for six weeks. The earthquake induced a radical shift in the way the PNG LNG project is perceived by its Huli landowners. Almost overnight the perception of state absence went from one of moral failing to active agent in the destruction of Hela. ExxonMobil went from misappropriated tool to malevolent partner in Hela's demise. The initial response to the earthquake was a widespread belief that it had been caused by the operations of the PNG LNG project. This belief had both a mythological and scientific basis and the two are not easily separated. That an earthquake should occur of such magnitude that it caused severe damage to project infrastructure as well as large areas of the PNG highlands, killing many and leaving many more in desperate need of assistance, was perfectly in line with the doomsday scenario that accompanied the Lai Tebo prophecy, as well as a more generalised entropic perspective of a world in constant decline. Many landowners as well as people across PNG and in the global activist community believed that the act of gas extraction had caused the tectonic activity that resulted in the earthquake. This view was supported by strong evidence that the process of fracking (a process not used by the PNG LNG project) has caused earthquakes elsewhere, particularly in the United States, and communicated via popular publications such as National Geographic (Gibbens 2017). The suspicion that the earthquake had been caused by the PNG LNG project was so strong and so widely held among business and political elites that the PNG government was moved to ask the Australian government to conduct a review into the cause of the earthquake, which it agreed to do via the services of Geoscience Australia (Anon. 2018).

An earthquake of such magnitude, occurring at that location, came as no surprise to anyone with an understanding of the history of tectonic activity in the PNG highlands. With the PNG LNG project shut down, the belief that the disaster had a metaphysical component was far from universal, and intense debate occurred on Huli social media networks where these views were often ridiculed. None of my Huli friends spoke to me in terms of traditional cosmology or prophecy. Rather, their concerns were framed around the inadequate response from the state and the plight of many 
who had been cut off from essential services. The aid post that serviced the Komo region was built on a low-lying area that sank into the ground due to liquefaction caused by the earthquake. Roads became impassable and desperately needed medical assistance was eventually supplied by the Australian military and Oil Search helicopters. It was these immediate concerns that were in the forefront of people's reaction to, and perception of, the earthquake.

The argument that prevailed more broadly across Huli society was a debate between two material causes: was it a natural or anthropogenic phenomenon? But at the same time the disaster was imbued with the sense that there was a moral component, not attached to its cause, but to its happening. For Huli, natural phenomena that happen without any particular cause, or those with a direct human cause albeit lacking in mindful intent, may still be classed within a family of events that are indicative of moral decline and a general trajectory of social and physical decay. The Oil Search managing director Peter Botten, was quoted as saying that the perception of an anthropogenic cause was 'a communications issue' (Barrett and Gloystein 2018). With this he missed a crucial point: the perception of the earthquake as having an anthropogenic cause was not a communications issue, but a development issue (Main 2018). Dozens of people were killed by landslides or collapsed buildings, however the majority of the suffering that resulted from the earthquake could be attributed to failing or non-existent infrastructure, a lack of government capacity at the local level, an absence of government response at the national level and the failure of the PNG LNG project to have contributed to a more developed Hela Province that would have otherwise been better placed to respond to natural disasters of any kind. In the eyes of the Huli, the earthquake also imposed a heavy moral status on the company, which had previously enjoyed a more morally neutral position. Lack of development was a moral failing of both the state and the project developer, and in the context of the earthquake, this lack, born of absence, became in itself a powerful agent of suffering.

\section{The Rise of ATALA}

Several weeks after the earthquake in June 2018, part of the PNG LNG project was attacked with new a level of ferocity and organisation by a group calling themselves the Angore Tiddy Apa Landowners Association, 
or 'ATALA'. ${ }^{13}$ Their attack was a direct response the earthquake and the impact of the absent state. ATALA was formed in 2014, declaring itself as the umbrella association for the Angore PDL8 landowners. According to ATALA's founding document the UBSA that was signed in May 2009 was done so before Petroleum Retention License (PRL) areas were converted into smaller Petroleum Development License (PDL) areas. ATALA were claiming that the social mapping was undertaken while Angore was still part of the old PRL11 and the results of this process were therefore null and void. It is beyond the scope of this chapter to undertake an analysis of the legal framework around petroleum development in PNG and I make no comment about the legitimacy or otherwise of ATALA's claims. Rather my intention is to provide an outline of the point of view of ATALA, who claim the support of 150 clans spread across the former PRL11 area, totalling some 100,000 people (Woods 2018a).

The gas resource tapped by the Angore wellhead is a later addition to the main resource at Hides and was planned to connect to the existing HGCP via an $11 \mathrm{~km}$ pipeline. The ATALA leadership is quite separate from the group that came together to blockade the HGCP in August 2016. But during that time ATALA gave their support for that action via their Facebook page, which has been the main forum for ATALA to communicate its objectives, which included asking 'the Member for Tari Pori, Minister for Finance and Government Business Leader, Honorable James Marape to acquit the Angore PDL8 Project Area Funds which he has been paying to his political cronies'. Up until February 2018, ATALA was primarily a political voice that was generally well-informed and articulate and engaged in online debate around PNG LNG land ownership issues and royalty payments. The 26 February earthquake induced a seismic shift in the attitude and approach taken by ATALA. The last post published by the association prior to the earthquake was a lengthy and considered statement related to the continuing issue of landowner identification and included the observation that 'Failures of successive attempts by the key State Agency stakeholders of the project is embarrassing for such an important project that underpins the economy of PNG for the next 30 years'. ${ }^{14}$ The first post published after the

13 It is more common to spell 'tiddy Apa' as 'dindi apa', which means 'land father'. The Huli 'd' is pronounced closer to the apical consonant sound of ' $t$ ' and is often interchangeable with ' $d$ '. It is unclear why the ' $n$ ' has been left out.

14 See: www.facebook.com/pg/angorePDL8/posts/?ref=page_internal (10 November 2017). 
earthquake simply stated: 'Our struggle is a struggle that has no definition to the Government and Stakeholders of the PNGLNG Project. One day, Hell will break loose!'15

On 21 June 2018, heavily armed ATALA representatives 'unleashed hell' on ExxonMobil's Angore camp, destroying buildings and machinery and shutting down the Angore tie-in project for the foreseeable future. Sources based in Tari told me that during this event 35 Papua New Guinea Defence Force (PNGDF) soldiers were flown by helicopter to secure the camp. The soldiers positioned themselves to mount an attack against the landowners but withdrew at the last moment when they realised that they were vastly outnumbered and outgunned. When the soldiers retreated, their helicopter was shot at. ATALA published an account of the attack on their Facebook page that included the statement: 'Exxon, we missed that chopper but its gonna come down. Look across and look at the smoke and flames. When you say so we talk.' ExxonMobil supplied the helicopter to the PNGDF for use in their action against the landowners. At the same time landowners at Komo under the umbrella leadership of ATALA placed a log across the Komo airfield to symbolise that they had shut down the facility for the foreseeable future.

Their actions were a clear violation of their own mission statement, which reads:

Work with honesty and integrity, and equitably share all benefits with neither fear nor favour.

Work hard and transform the wisdom of the laitebo prophesy into socioeconomic and political achievements for the Angore people now and into the future.

Negotiate without violence, and work honestly and diligently with the key stakeholders of the PNGLNG Project.

The principle of negotiation without violence was buried with the earthquake, and this change in approach is documented in a statement released on 21 May 2018 that asserts: 'Since the EQ Disaster in the Hela, Southern Highlands, Gulf and Western Province; the shift of the negotiating power is now with the people.' This statement gets to the core of the fundamental shift in power relations between people and 
the state that was created by the earthquake. The earthquake provided ATALA with the moral authority to assert themselves as a military power and to bypass the practice of negotiation and deploy violence to achieve their ends. In this action, ATALA has made a concerted effort to gain the support of a large number of clans across a greater part of Hela. State neglect in the context of the earthquake and its aftermath has become a form of structural violence, as the inability and unwillingness of the state to provide adequate disaster relief has resulted in increased suffering for a great many people. For ATALA and many Huli landowners the earthquake amounted to the total collapse of the value proposition that is the state of PNG. This opened up the space for ATALA to reinvent itself as a morally superior alternative to the state. Furthermore, the failure of the state to respond to a natural disaster of such magnitude removes the logic that accompanied previous efforts at negotiation and the pursuit of state-based mechanisms such as court actions and political directions. For ATALA and its supporters, violent action has become both a morally justifiable and rational method of advancing their cause. Hela must assert itself as a nation without the need for a state, since the value proposition that is the state barely exists. State neglect has become more than just a source of frustration and a perceived moral failing-it has emerged as a form of negative agency that must be combatted.

The boldness of ATALA was expressed not just through violent action, but in its demand for a stand-alone gas stripping facility for the Angore resource, and its offer to buy ExxonMobil out of its gas resource at Angore. A statement released by ATALA on 20 June 2018 asserts a sovereign claim to the gas resource, something that had previously been ceded to the state in the expectation that the state and developer would act in the best interests of the landowners:

In Angore, ATALA Incorporated is the landlord, not the government of Papua New Guinea. ATALA Incorporated has taken over Angore PDL8 Operations including the 5.4 Trillion Cubic Feet of LNG.

This project, the PNGLNG Project, has brought curse and suffering to the people of Angore and we will need that now. ATALA Inc as the landlord is taking over the Angore PDL8 and will develop separately from the PNGLNG Project. 
The document then outlines in some detail the economic mechanisms by which the Angore gas resource is to be utilised specifically for the benefit of the landowners within PDL8. It goes as far as demanding 'a standalone gas stripping facility so as to determine and quantify how much LNG and Condensate are produced from our reserve which is an independent service to other gas-fields within and outside of the Hela Province'. The political impact of the earthquake was to negate the state and its development apparatus in ExxonMobil as legitimate entities. Instead of desiring the absent state to become materially present, the material consequences of state absence in the context of the earthquake reversed this desire: the absent state bereft of value was to be banished altogether. Emerging from this negation is an organisation within the nation of Hela that believes it has no choice but to go it alone, backed by a sense of legitimacy based on a concept of Gigira Lai Tebo, which provides both the entitlement to the benefits of the gas resource and the moral authority to control it.

\section{Conclusion: The State of Nothing}

The PNG LNG project has profoundly shaped the PNG economy, and has helped to define PNG as a state that has absented itself from its basic obligations to its own people. The PNG LNG project has simultaneously transformed and helped to define an understanding of Hela as an Indigenous nation endowed with resource wealth and entitled to a parent state that can fulfil its development aspirations. The experience of an absent state in Hela Province in the context of greatly increased expectations of the state resulting from the PNG LNG project reveals the extent to which the state itself is a concept that exists as a shared idea that may increase in salience as the material presence of the state disappears. The PNG LNG project was expected to enhance the value proposition of the state by enabling it to provide a bonanza of promised development projects as well as direct cash payments to landowners. The state exists materially in the form of the built environment that is constitutive of its value: the schools and hospitals, roads and services that the state is expected to provide. The state also exists materially in the form of its representatives who hold positions of power and authority who are valued for their ability to deliver development outcomes. At Hides in August 2016, when this absence became intolerable to a group of Huli elites, they were able to exercise power over the state using the PNG LNG project as a proxy, and force the state to become present and to take notice of those 
that it had been refusing to acknowledge. One Huli elite, the minister for finance James Marape, was caught between his identity as a son of Hela, and his role as a representative of the state. As part of the state Marape could retreat into absence, but Hela was part of Marape and that was a presence that he was unable to deny.

This chapter has demonstrated how the concept of state absence took on a special significance in the context of the state's failure to respond to natural disaster. The state, as an externalised, parental authority, derives its legitimacy and is defined as a value proposition through its ability to service the viability of the nation of Hela. The destructive power of the earthquake of February 2018 was the ultimate exposure of the state to the abrogation of its most fundamental responsibilities. Where corruption and neglect had only made the state loom larger for its absence, the trauma of the shaking of Hela has turned this absence into a form of active malevolence. In the process, ExxonMobil has become a weapon rather than a tool of the state, and has endured the consequences at Angore. On 26 June 2018 the PNG government offered ATALA PGK20 million in return for ending their protest (Woods 2018b). The landowners rejected this initial offer, asking that the state also provide their organisation with official recognition as a legitimate organisation, to which the state duly complied. With this request the landowners were keeping a foot in both camps, as they were simultaneously trying to bypass the state and asking to be recognised by the state and extracting as much value from the state as they could. The state continues to exist, even as its existence is repelled, as its value has not entirely collapsed. It is unclear how the future will unfold for Hela and the PNG LNG project, however the granting of cash and negotiating power to ATALA as an official organisation has thus far prevented further attacks against the project, as no further threats have emerged from this organisation. In both August 2016 and June 2018, landowners demanded that the state 'present itself', and on both occasions the state complied. But these occasions have only had the effect of satisfying the demands of particular landowner leaders and their supporters, many of whom had borrowed substantial amounts of money in the expectation that a development windfall was coming, and needed the state to bail them out when the debt collectors started calling. These protests, although made possible by the absence of the state, have done nothing to create the substantial reform that is desired and expected by the broader Huli population. As the gas continues to flow and be shipped out to be sold offshore, it remains to be seen whether Hela landowners will continue to tolerate the impact of the state's absence into the future. 


\section{Postscript}

On 12 April 2019, James Marape resigned as finance minister, citing disagreements with the prime minister over the signing of the agreements for the new Papua LNG project in neighbouring Gulf Province, which appears destined for a similar fate to that of the PNG LNG project. The next day Marape returned to Tari, the capital of Hela Province, to a hero's welcome, stating that the government had brought nothing tangible to Hela, only promises. After seven years as finance minister of an absent state, Marape chose to be present as the representative of the Nation of Hela as his self-perceived value as a representative of the state was finally exhausted. On 7 May 2019 Marape was elected 'alternative prime minister' by PNG's opposition party, and, after a complex succession struggle, was sworn in as prime minister on 29 May. Marape's rise has done much to dissolve the boundary between the nation of Hela and the state of PNG. Marape based his power struggle on the failure of PNG to benefit from its considerable extractable resources, and, following his swearing in, immediately called for economic independence for PNG, and derided the systemic impairment of the translation of PNG's 'opportunities and blessings' to its people (Auka-Salmang 2019). Since then Marape's 'take back PNG' rhetoric has been consistent, bold and has translated into robust policy positions (Kama 2019). Marape has thus far maintained a consistent position in negotiations between the state and ExxonMobil over the P'nyang gas field, and, in February 2020, suspended negotiations describing ExxonMobil's position as 'unacceptable', stating that PNG's resources must 'allow us to improve our people's way of life. We don't believe the last offer made by ExxonMobil would have done that' (Wilkinson 2020).

By the time of writing, in July 2020, Marape has thus far avoided the pitfalls of his predecessor, has the appearance of being genuine in his motives and engages much more intimately with PNG's extraordinarily diverse grassroots population. Marape communicates directly to the nation via Facebook, making himself present in households across the country, and was initially signing off with the Huli term 'Hulukuyama'. This is a praise term for a Huli man, and will only be recognisable to Huli speakers. Huli could not be more legible to the state, and yet their struggle to obtain state royalty payments for the PNG LNG project continues. The reason for this is that their struggle is about making themselves legible internally, rather than to the state. Dispute over land ownership 
is part of a centuries-old argument over the control and interpretation of Huli land ownership history, and this has intersected with disputes over royalty payments. But royalty payments are not what the promise of the PNG LNG project was ever about. It is about development, and that means infrastructure, it means services, it means meaningful employment, improved standards of living - all of which are only possible via the accumulation of capital, and the effective use of capital. Royalty payments to thousands of landowners are about the thinning of capital, they are not a pathway to development, and they have never been the sole objective of the Huli population. Royalty payments are at least an indication that the state is paying attention, and that perhaps real development might be possible. It is arguable that the PNG LNG project, and its stark reveal of an absent state, are responsible for Marape's rise to power. Marape's term might finally reveal whether the presence of the extractive industries, and the activities of multinational extractive corporations, should even be considered as viable pathways towards the development of the nation.

\section{References}

ACIL Tasman, 2008. 'PNG LNG Economic Impact Study: An Assessment of the Direct and Indirect Impacts of the Proposed PNG LNG Project on the Economy of Papua New Guinea.' Melbourne: ACIL Tasman Pty Ltd for ExxonMobil.

Anderson, B., 1983. Imagined Communities: Reflections on the Origin and Spread of Nationalism. London: Verso.

Anon., 2018. 'PNG Earthquake: Calls for Formal Inquiry into Cause as More Aid Arrives, ADF Sends Globemaster Packed with Supplies.' Australian Broadcasting Corporation, 10 March. Viewed 29 September 2020 at: www.abc. net.au/news/2018-03-10/calls-for-inquiry-into-cause-on-png-quake/9534898

Auka-Salmang, G., 2019. 'Marape Sworn in as Country's 8th PM.' Post-Courier, 30 May.

Bainton, N., 2021. 'Menacing the Mine: Double Asymmetry and Mutual Incomprehension in the Lihir Islands.' In N. Bainton, D. McDougall, K. Alexeyeff and J. Cox (eds), Unequal Lives: Gender, Race and Class in the Western Pacific. Canberra: ANU Press. doi.org/10.22459/UE.2020.14

Ballard, C., 1994. 'The Centre Cannot Hold: Trade Networks and Sacred Geography in the Papua New Guinea Highlands.' Archaeology in Oceania 29(3): 130-148. doi.org/10.1002/arco.1994.29.3.130 
1995. The Death of a Great Land: Ritual, History and Subsistence Revolution in the Southern Highlands of Papua New Guinea. Canberra: The Australian National University ( $\mathrm{PhD}$ thesis).

_ 2000. 'The Fire Next Time: The Conversion of the Huli Apocalypse.' Ethnohistory 47: 205-225. doi.org/10.1215/00141801-47-1-205

- 2002. 'A History of Huli Society and Settlement in the Tari Region.' Papua New Guinea Medical Journal 45(1/2): 8-14.

Barrett, J. and H. Gloystein, 2018. 'Shakes and Superstition: Exxon Faces Backlash in Papua New Guinea.' Reuters, 8 March.

Biersack, A., 1995. 'Introduction.' In A. Biersack (ed.), Papuan Borderlands: Huli, Duna, and Ipili Perspectives on the Papua New Guinea Highlands. Ann Arbor: University of Michigan Press. doi.org/10.3998/mpub.14775

Blong, R.J., 1979. 'Huli Legends and Volcanic Eruptions, Papua New Guinea.' Search 10(3): 93-94.

, 1982. The Time of Darkness: Local Legends and Volcanic Reality in Papua New Guinea. Canberra: Australian National University Press.

Bourke, R.M., B. Allen and M. Lowe, 2016. 'Estimated Impact of Drought and Frost on Food Supply in Rural PNG in 2015.' Canberra: The Australian National University, Crawford School of Public Policy, Development Policy Centre (Policy Brief 11).

Chernilo, D., 2006. 'Social Theory's Methodological Nationalism: Myth and Reality.' European Journal of Social Theory 9: 5-22. doi.org/10.1177/1368431 006060460

Cuthbert, N., 2009. 'The Hela Prophesy.' Malum Nalu blog, 22 November. Viewed 29 September 2020 at: malumnalu.blogspot.com.au/2009/11/helaprophesy.html

Ernst, T., 2008. 'Full-Scale Social Mapping and Landowner Identification Study of PRL02.' Unpublished report to ExxonMobil Ltd.

Esdale, F.V., 1955. 'Tari Patrol Report No. 6 of 1954/55.' Patrol Reports. Southern Highlands District, Tari, 1954-1955. National Archives of Papua New Guinea, Accession 496.

Filer, C., 2014. 'The Double Movement of Immovable Property Rights in Papua New Guinea.' The Journal of Pacific History 49: 76-94. doi.org/10.1080/ 00223344.2013 .876158 
2019. 'Methods in the Madness: The "Landowner Problem" in the PNG LNG Project.' Canberra: The Australian National University, Crawford School of Public Policy, Development Policy Centre (Discussion Paper 76). doi.org/10.2139/ssrn.3332826

Flanagan, P. and L. Fletcher, 2018. 'Double or Nothing: The Broken Economic Promises of PNG LNG.' Sydney: Jubilee Australia.

Frankel, S., 1986. The Huli Response to Illness. Cambridge: Cambridge University Press. doi.org/10.1017/CBO9780511521072

Galtung, J., 1969. 'Violence, Peace, and Peace Research.' Journal of Peace Research 6(3): 167-191. doi.org/10.1177/002234336900600301

Gibbens, S., 2017. 'How Humans Are Causing Deadly Earthquakes.' National Geographic, 2 October.

Goldman, L., 1981. Talk Never Dies: An Analysis of Disputes Among the Huli. London: University College London (PhD thesis).

— 1983. Talk Never Dies: The Language of Huli Disputes. London: Tavistock.

GPNG (Government of PNG), 1975. Constitution of the Independent State of Papua New Guinea. Port Moresby: National Parliament.

_ 2013. 'National Population and Housing Census 2011: Final Figures.' Port Moresby: National Statistical Office.

Kama, B., 2019. “"Take Back PNG”: Prime Minister Marape and his Audacious Vision for PNG.' DevPolicy blog, 8 August. Viewed 23 September 2020 at: devpolicy.org/take-back-png-prime-minister-marape-and-his-audaciousvision-for-png-20190808/

Main, M., 2018. 'How PNG LNG Is Shaking Up the Earthquake.' Envirosociety blog, 28 March. Viewed 23 September 2020 at: www.envirosociety.org/ 2018/03/michael-main-how-png-lng-is-shaking-up-the-earthquake

Patrol Reports. Southern Highlands District, Lake Kutubu, 1953 - 1954. National Archives of Papua New Guinea, Accession 496.

Scott, J., 1998. Seeing Like a State: How Certain Schemes to Improve the Human Condition Have Failed. New Haven (CT): Yale University Press. doi.org/ 10.2307/j.ctvxkn7ds

Terrell, C.E.T., 1953. 'Lake Kutubu Patrol Report No. 3 of 1953/54.'

Tzu, L., 1963. Tao Te Ching (trans. D.C. Lau). London: Penguin Classics. 
Wilkinson, R., 2020. 'PNG stops P'nyang Gas Agreement Negotiations with ExxonMobil.' Oil and Gas Journal, 3 February.

Woods, L., 2018a. 'Papua New Guinea Landowners Take Up Arms Against Natural Gas Project.' Mongabay blog, 26 June. Viewed 23 September 2020 at: news.mongabay.com/2018/06/papua-new-guinea-landowners-take-up-armsagainst-natural-gas-project/

_ 2018b. 'Deal in Sight for PNG Landowners Protesting Exxon-Led Gas Project.' Mongabay blog, 31 August. Viewed 23 September 2020 at: news.mongabay.com/2018/08/deal-in-sight-for-png-landowners-protestingexxon-led-gas-project/

World Bank, 2017. 'Papua New Guinea Economic Update, December 2017: Reinforcing Resilience.' Viewed 23 September 2020 at: documents.world bank.org/curated/en/150591512370709162/Papua-New-Guinea-EconomicUpdate-Reinforcing-Resilience.pdf 
This text is taken from The Absent Presence of the State in LargeScale Resource Extraction Projects, edited by Nicholas Bainton and Emilia E. Skrzypek, published 2021 by ANU Press, The Australian National University, Canberra, Australia.

doi.org/10.22459/AP.2021.05 